\title{
Daily Experience of HIV Positive: a Qualitative Study
}

Micheline Maria Laurindo de Souza1, Elicarlos Marques Nunes², Maryama Naara Felix de Alencar Lima³, Juliane Oliveira Costa Nobre ${ }^{4}$, Sheila da Costa Rodrigues Silva ${ }^{3}$, Milena Nunes Alves Sousa ${ }^{5}$, Manuela Carla Souza Lima Daltro ${ }^{6}$, Raquel Campos de Medeiros ${ }^{7}$, Ana Paula Dantas de Silva ${ }^{8}$, Cristina Costa Melquiades Barreto ${ }^{4}$, Erta Soraya Ribeiro Cesar Rodrigues ${ }^{4}$, Rosa Martha Ventura Nunes ${ }^{4}$, Elainy Maria Dias Medeiros França ${ }^{3}$, Kamila Nethielly Souza Leite ${ }^{8}$, Hellen Renatta Leopoldino Medeiros ${ }^{9}$, Denisy Dantas Melquiades Azevedo ${ }^{9}$, Thoyama Nadja Felix de Alencar Lima ${ }^{3}$

\section{Abstract}

Introduction: Syndrome Immune Deficiency Acquired (also called Acquired Immune Deficiency Syndrome) is still a disorder linked to death and of great social paradigm. The HIV-positive tend to have psychological and emotional distress. Being an HIV positive even in today's times is still difficult to accept, because of the negative way in which the disease has been exposed since its discovery.

Objective: To investigate the daily life of HIV positive, according to its insertion in the family and in society.

Method: This is a qualitative study with two 02 people with HIV, who are attended by the Social Aceve NGO in Patos county, Paraíba, Brazil. Techniques Used: ethnographic observation and in-depth interviews.

Results: One of the respondents, to be diagnosed positive for HIV reacted so angry even thinking about suicide, however he had the full support of family and close friends, thus contributing to the overcoming of new HIV status. The other respondent joined the silence as a form of protection, believed that in this way is shielded against discrimination but that attitude acts negatively for the individual and for others, this is a major barrier in control and in combating the epidemic.

Conclusion: The study allowed us to understand in a more embracing way some problems that arise in the Syndrome Immune Deficiency Acquired disease. Especially, those relating to the prospects of life and disease coping alternatives. It was noticed that the HIV infection more than a problem to be faced by health services, should be considered a social and cultural phenomenon quite complex, where there
1 Graduate nurse by Patos Integrated College, *.

2 Nurse. Master in Public Health. Teacher, Department of Nursing of Patos Integrated College, *

3 Nurses. Masters in Collective Health. Teacher in nursing department of Patos Integrated College, *

4 Nurses. Masters in Health Sciences. Teacher, Department of Nursing of Patos Integrated College, *

5 Nurse. PhD in Health Promotion. Teacher at medicine departament of Patos Integrated College, *

6 Physiotherapist. Master in Health Sciences. Teacher, Department of Physical Therapy of Patos Integrated College (PB), Brazil.

7 Nurse. PhD in Health Sciences. Teacher and Coordinator of the Nursing Department of Patos Integrated College, *

8 Nurses. Masters in Nursing. Teacher in the nursing department of Patos Integrated College, *.

9 Nurses. Specialists. Teachers in the nursing department of Patos Integrated College, *

*: Patos (PB), Brazil.

\section{Contact information:}

\section{Elicarlos Marques Nunes.}

Address: Horacio Nobrega Street, s/n. Neighborhood: Belo Horizonte, Patos, PB, Brazil. CEP: 58704-000.

” elicarlosnunes@yahoo.com.br 
is a very large discrimination holders and a lot of lack of knowledge on the part the population of this infection, meriting the use of new methodological approaches.

\section{Keywords}

Qualitative Study; HIV/SIDA;

Carriers Experience.

\section{Introduction}

The Syndrome Immune Deficiency Acquired - SIDA has the agent of human immunodeficiency virus HIV as its etiological agent. The virus affects the immune cells of our body, preventing the immune system's protective function of the human being, thus leaving it susceptible to attack of infectious agents. SIDA is still one of the serious problems of global public health and it is termed as a global epidemic affecting all continents, with a rapid spread in the population.

Given the seriousness of the disease it is necessary rapid and effective responses covering the economic resources needed for the maintenance of public health, spreading the disease to the knowledge and understanding of the population, political, social and psychological resources that face a problem with such magnitude. The person living with HIV and its family can live personal and social dramas in everyday life, because of prejudice, the paradigm, the fear of death, the loneliness and the silence that the carrier tends to adhere because of the prejudice that unfortunately still exists in society and with the carrier's own syndrome [1].

According to the latest Epidemiological Bulletin of the Ministry of Health (base year 2010), in Brazil. Were reported in the System of Notfiable Diseases Information (SINAN), 608,230 SIDA cases, accumulated from 1980 to June 2011, 397, 662 (65.4\%) were male and 210,538 (34.6\%) were female [2].

Prejudice and discrimination experienced by people living with HIV in their personal and social spaces trigger silent about the positive diagnosis for HIV, this silence tends to be adhered as a form of defense, and this attitude acts negatively for the individual and for others, this is a major barrier in control and in combating the epidemic, making difficult the appropriate support, care and treatment of SIDA and its diagnosis. Positive sera avail themselves of this silence as a measure of protection and prevention of discrimination, because they fear that such attitude can result in social exclusion. The need to maintain silence often creates in the positive sera the condition of does not have someone to share their doubts, fears, anxieties about their health condition, which puts them in a vulnerable situation because they feel isolated and different from the rest of society [3].

The way to cope with the disease begins with the very acceptance of the pathology from the individual infected, through communication and easy access to information for the understanding of the syndrome, provided in a clear and easily understandable, considering the capacity for learning of each person and its limitations. These forms of communication influence the attitude of understanding from the infection for both the carrier and for his family, and along with family support these actions contribute to adherence to treatment.

With the clarification of what is SIDA the individual will understand that it is in today's times, with the use of cocktails (group of medicines used to treat HIV) it lost its lethality turning into a chronic, manageable disease. With psychosocial support the carrier of the condition will feel valued and not excluded by society, understood and less discriminated, thus contributing in a very significant way to the better adherence to treatment [4]. 
Social support is essential to human life, especially in periods of transition and change, when of course are necessary adaptations and the individual goes through stressful situations [5].

According to the Ministry of Health personal patient bias also has great influence to the noncompliance of treatment and non-acceptance of the disease, if there is no professional intervention of health for the advice and guidance of the importance of treatment, the course of the disease leads the serious damage, compromising from the wearer's health to the spread of resistant virus by the population, thus reducing the possibilities to control the pathology [6].

Universal access to antiretroviral therapy (HAART) has resulted in a significant reduction in morbidity and mortality rates from SIDA. The care of people living with HIV/SIDA involves great challenges. Thirty years since the first cases of SIDA in Brazil, actually we are living with a disease that has a specific treatment, without having experienced the high mortality rate that marked the beginning of the epidemic. On the other hand, with the increase in survival, quality of life of people living with HIV/SIDA have gained increasing importance [2].

The Ministry of Health recommends that health professionals, in disclosing HIV diagnosis, especially when positive, offer emotional support and guidance that help to alleviate the anxiety and answer questions. Among these guidelines, it is important to differentiate between HIV and manifestations of SIDA, availability of treatment and its offer for $\mathrm{Na}$ tional Health System and the steps to be taken to avoid the possibility of HIV transmission [7].

Counseling is an important step and should always be performed before and after the test, thus highlighting the emphasis of compliance with treatment, the importance of it, direct the client for monitoring by a multidisciplinary team, which can a joint, offer support for coping with the disease and adherence to chemoprophylaxis, thus covering all needs and difficulties encountered in the situation of a positive diagnosis for HIV. Family participation is of paramount importance to adherence to treatment, thereby contributing to the physical and mental balance of the HIV carrier [8].

Given the above came the following questions: How is HIV carrier experience before his family and society in which it is inserted? What has changed after the discovery of the disease? Who supports him/her?

The relevance of this study is justified because the HIV virus, more than a problem to be faced by health services, should be considered a social and cultural phenomenon quite complex, in which there is a very large discrimination with carriers and much lack of knowledge by the public about this infection, meriting the use of new methodological approaches.

Thus, this study aimed to identify new elements that contribute to better contextualize the HIV infection and the experience of its sufferers, especially to identify the issue of social exclusion, in order to provide new insights for the formulation of public policies that promote equity, in this context it aims to investigate the daily life of HIV positive patient, according to its insertion in the family and in society.

\section{Methods}

The present study had a qualitative approach and was conducted with people living with HIV in the city of Patos, Paraíba (PB), Brazil, which are attended by the NGO Social ACEVE that develops social work, among them the HIV/SIDA program.

Qualitative research has, as the main source, the environment, where the researcher has direct contact as much as environment as the object of study, considered the need for field work [9]. This research differs from quantitative because it not prioritize statistical data and thus consider the interpretation of the phenomena and the attribution of meaning. 
The study included only two [02] people with HIV followed at NGO ACEVE social in Patos-PB therefore, there were [07] people being together, these two [02] came to death before the interview consolidation and three [03] refused to participate in the research.

Participants who agreed to participate the research signed a Consent Form Free and Clarified - CFFC, according to the following inclusion criteria: Having HIV virus and been accompanied in the $\mathrm{NGO}$, accept to participate the study after clarification related to the research [10].

The study was conducted using a semi-structured interview guide containing subjective questions previously prepared by researcher contemplating the proposed objective.

After the project was approved by the Ethics Committee, with opinion number 912470 data were collected through interviews, on days and times previously established, according to the availability of respondents. The researcher has to make the interviewee feel free to make his/her story, because the underlying wealth to these lines is irreplaceable in terms of source of information [11].

We must encourage him to tell everything in detail, their fears, their anxieties of non-inductively way. In addition to the textual wealth of speech, shines in the eyes of the researcher, a specific individual, a member of a complex and rich culture should also be considered.

\section{Results and Discussions}

\section{Ethnographic observation}

It is presented here the results of ethnographic observation step held at the NGO Social ACEVE in Patos-PB, and some general comments from interviews with people living with HIV attended in that service.

The observation period was from January to March 2015, contemplating the morning hours (7am to $11 \mathrm{am}$ ). This stage of the research aimed to know the operation of the service for the care of HIV carriers in the unit above.

The results described herein are the result of ethnographic observation and informal conversations with social volunteers of the NGO Social ACE$V E$ and in-depth interviews with people living with HIV attended in this NGO. The researcher with a comparative look, fed by vast literature searches, can get away from his own universe to set him in sociological and cultural terms. To draw any conclusions of its material, it becomes necessary to place his subjects in a social and historical context. And to complete this interpretation, going from the particular to the general, he creates an ethnographic account. The author adds that without this "context" (a type of representative post ipso facto), the "qualitative" does not add much to the academic reflection [12].

\section{Interviews in deep with sera positive for HIV}

The participants were two adults, been one man (fictional name of Antônio) and a woman (fictional name of Madalena), aged from 30 to 55 years, one of them in drug treatment process (anti-retroviral) for at least two years, and the other does not make any kind of treatment. Participants are monitoring in the NGO Social ACEVE the city of Patos-PB, the interviews were conducted in the period from January to March 2015.

The interviews were recorded and lasted forty (40) minutes to One (01) hour. From the (02) interviews, one was held at the Regional Hospital of Patos and the other at the NGO. Both were previously scheduled and informed by the coordinator of the NGO social program.

The main difficulty encountered in the period of the interviews was the fact that it is a subject still very controversial and that there is a lot of prejudice for own carriers, so few attended the NGO refused to participate in the study. 
To facilitate the interpretation of the data and maintain the anonymity of the interviewees, the names have been changed by codenames as guide Minayo, Assis and Souza [13].

\section{Categories}

Now the results that were emerged from the speeches of HIV carriers in the interviews will be presented, together with ethnographic observation with respect to everyday experiences of HIV positive. These data were organized into the following categories: "Discovery of Disease"; "Feelings to find the disease"; Changes in life after the disease "; "Fears"; "Family and friends reaction"; "Preconception"; "Plans for the future".

\section{Discovery of Disease}

By questioning the respondents about how he was discover (d) to be HIV positive, the answers are completely different, because one of the participants showed signs and symptoms while the other showsed no symptoms, making it an asymptomatic carrier. Thinking until she is no virus carrier.

It was a warmth in the blood, the blood boiling on fire, retching, diarrhea a lot, and lack of appetite, a lot, got sick, went to the hospital from there, and the doctor disabused me, sent me to Campina Grande, from Campina I was sent to João Pessoa, from Joao Pessoa they turned me to Campina Grande again, then the Doctor who helped me soon demanded me these exams, required me these tests, then when there was as tomorrow I did, the other day I got the tests and was proved that I had

Antônio, 54 years.

I discovered when I had my youngest girl, at last pregnancy, did prenatal but I just found in time to have her in the maternity, did all prenatal and never consisted anything, just came already present at the time to have a girl, in childbirth

Madalena, 32 years.
Note the difference in the way in which the respondents discovered they were HIV positive, one was through signs and symptoms and the other at the time of giving birth through a quick test at the hospital.

After the discovery of being HIV positive, the woman is faced with personal, family and social difficulties. Lives with the anguish of the silence, hiding the diagnosis in an attempt to keep the marriage and family relationship or even to be a mother [14].

The Ministry of Health recommends that health professionals, to disclose HIV diagnosis, especially when positive, offer emotional support and guidance to help alleviate anxiety and answer questions. Among these guidelines, it stands out as important the difference between HIV and manifestations of SIDA, availability of treatment and its bid for $\mathrm{Na}$ tional Health System and the cares to be taken to avoid the possibility of transmission and spread of HIV [2].

The Ministry of Health recommends conducting the HIV test, with advice and consent to all pregnant women at the first prenatal visit. Determines further that, whenever possible, the HIV serology is repeated, at the beginning of the third quarter, aiming at maternal and child health, with emphasis on prevention of vertical transmission to the newborn. When the testing is not performed during the prenatal, it must occur at birth, through the rapid test [15].

\section{Feelings to Discover the Disease}

On being questioned about how they felt upon discovering the disease, one of the respondents show an angry way, who thought up to take his own life, the other respondent due to her lack of knowledge about the disease received the news in a normal way, without showing any concern or fear, taking advantage of the silence and rejection of pathology. 
Before I call home has come the urge to do anything to take my own life, before giving the news with afraid of my wife's reaction, my daughters, my fear was unbearable, my wife was the first person I gave the news, then she did not believe, then she said I do not believe, if I go home I take the exams for you to see, and for the girls to see, the first to know is you, if I go home, why if I do not, you can go arranging my funeral I do not return home alive.

Antônio, 54 years.

Feel nothing, I'm not afraid of anything, I am totally quiet, I do not believe I have the disease, even as it has the man, the guy who already lived, always did the exam and everything, and never gave anything in it, for what I do not believe I have.

Madalena, 32 years.

The initial fear displayed by the first respondent, Antônio, 54 years old, is due by the binding of the disease's to death and the fact that both the SIDA disease and its treatment is still a little discussed and known by society in general. Antônio discovered the disease in 2013.

The second interviewee, Madalena, 32 years old, who discovered the disease in 2009 claimed not feel anything and did not show any fear of being diagnosed HIV positive, facing the disease with greater ease. This statement, might be interpreted as a denial mechanism by interviewed in order to protect herself from her current reality. Reducing the perceived severity of a disease can often mean an attempt to assuage the anxieties related to death. However, this is a question that varies widely according to the psychological characteristics of each. An HIVpositive may react to the disease with an exaggerated emotional charge or almost indifferent, and can also switch pictures of anxiety and depression [16].

Study accomplished with 20 HIV positive participants in 2008 has been found that, initially, the fact of they discover themselves HIV positive triggered in patients a variety of feelings whether of fear or indifference. However, over time, this difficulty gives way to other feelings such as appreciation of life and change in daily life with a view to improving their quality of life. The studied showed that, despite being treated at a specialized service, they still find difficult to understand the disease [17].

\section{Changes in Life after Illness}

Asked by which changes their lives had after the discovery of being positive sera for HIV, one of the interviewees is fully aware of his condition and knows that through the treatment and clarifications that had for health professionals about the disease, he knows that he can have a normal life, with proper care, while the other interviewed by not having any symptoms until think that she does not have the disease, and continues her "normal" life without due care or treatment.

No change of life, I continue my life normally, with the advice of the doctor, Friends and support of the doctor. Here when I was transferred, a psychologist advised me too well and said I could lead my life in front, with the support I had, I kept my normal life, I did not feel anything, over time I have been taking the medication, it is over the vomit craving, it is over the warmth in the blood, just everything, everything, everything, thank God I did not feel anything or boredom felt more, what worried me most was the warmth that started a fire, from the soles of the feet until the core head, that fire that I was in agony, ran to the bathroom before the treatment, that's because it is good to take the exam, because sometimes we think we do not have and have, because I never dreamed I'd have this problem.

Antônio, 54 years. 
Nothing has changed, I continue with my normal life, sometimes not even believe that I have this, I think sometimes I have no disease, I do not feel anything.

Madalena, 32 years.

After its discovery in Brazil in the mid-80's, it can be noticed a positive development concerning to the quality of life of positive serous for HIV, with treatment, care and clarity of what it is the disease, carriers can have a perspective of long life, thus having a better quality of life. With this, SIDA is replaced by features of chronic disease and not a disease linked to death [18].

The evident success in the quality of life of sera positive for HIV was associated with the launch of a new drug, which was presented by science in 1996, and showed an effective response, in the inhibition of protease protein (a protein responsible for the transition of RNA from DNA viruses for human cell). After a few years the rise, it was possible to notice a significant drop in deaths from SIDA in the world. If in 1996 there were more than 15,000 deaths in Brazil. In the following year, the index fell to 12,078 and to 10,770 in 1998 [6].

In this context, through studies conducted with eight participants in the city of Recife-PE demonstrate that living with HIV has been strongly linked to stigma of death and prejudice [19]. It is of great importance to strengthen the educational forms and emotional support at diagnosis to further combat the serum positivity condition. The reduction of the social and emotional impact of the diagnosis is seen as key element for accession to future treatment plan and to living with HIV.

\section{Fears}

Before the questioning about their fears, one respondent clearly understands the magnitude of the condition, knows what care should follow so that will not have complications, while the other showed relapse, without any fear, does not understand the risk she runs and that makes others go due to her non-acceptance of the disease. So, spreads the virus to the population without even prove minimal concern.

My biggest fear is I stay like that person I saw there in the Screening and Counseling Center - CTA, when she came out was already dying, I think that this woman did not live longer, I did not see her no more the CTA, this is my biggest fear of being in that situation, she was the first person I saw who had the same symptoms I was, she was a young woman, I think she did not have 30 years and she was finished, her arms was the fineness of a finger, the legs, mercy, seemed a triangle that there... Oh, that gives me the strength to continue the treatment and never miss a consultation, and not missing without medication.

Antônio, 54 years.

I'm not afraid of anything, I am totally quiet, I do not believe I have the disease, even because it has the man, the guy who already lived, always did the exam and everything and never gave anything, so I do not I believe I have. I do not do the treatment because I don't want to, I've been a few times I went to Joao Pessoa do the treatment, but people began to suspect that I had any disease so I did not came anymore.

Madalena, 32 years.

In this context, the possible physical changes show a constant concern in the daily lives of these individuals. It affects in psychological aspects, since the change of look results in much pain affecting the self-esteem, thus may cause the individual depression, thereby making it difficult to fight and control of the disease.

The individual acceptance of the disease, the social and emotional context in which the diagnosis was made interfere in a comprehensive way for the acceptance or non-adherence to treatment. Studies 
show that when they receive positive diagnosis for HIV/SIDA, even with pre and post counseling, the subjects showed an angry way and denial the no accepting of the disease, thinking they will die quickly or simply refuse to accept, thus hindering the control of the epidemic, and a better quality of life [20].

The membership concept brings out how the patient accepts his condition, how knows and activates their individual, psychological, emotional and social resources to face her, adherence to treatment is beyond the comprehension of just taking medication, or when the individual effects examinations of control, it is considered the action medical prescription and to take necessary medicine more not enough for a good treatment of the disease [21].

\section{Reaction of Family and Friends}

Asked how was the reception of family and friends, we realize that when there is a host family and people close, "friends", there is a better individual acceptance of the disease, thus making it easier the adherence to treatment and their awareness of the care needed for no spread of the virus to the population and better quality of life for the infected individual.

I had no prejudice of my family, from nobody, my father and my mother were alive, but today every two have died, they supported me, my wife and my children never had a little prejudice, my brothers supported me, closed neighbors, my friends had no prejudice.

Antônio, 54 years.

My family did not know, nobody knows, never mentioned it to anyone

Madalena, 32 years.

Social support is defined as the action taken by groups or people of great personal significance (family, friends or neighbors), in some moments of life.
With all the subjectivity and individuality of social support will depend on how each individual receive and interpret. For such support is necessary in principle acceptance of the disease, to be clear and not be afraid to express their doubts, fears and needs [22].

Family and close friends help significantly represent the way that strengthens and motivates the carriers of the virus for monitoring and adherence to treatment of the disease. Social support is very important for every human being, especially in moments of discovery and change, when adaptations are of course necessary for the overcome of the stress situations. The discovery of being HIV positive is a moment that the individual undergoes major changes and must adapt, so that only then can accept the conditions of the new life [23].

In this context the authors emphasize that social support is shown as a large magnitude action that involves a positive link between the infected person and his social field, thus contributing to the satisfaction of social needs, promoting completion so there facing the new existing conditions.

\section{Preconception}

When asked about the positioning of the society in the face of SIDA pathology, patients proved unanimous in demonstrating that there is a prejudiced and discriminatory position on this issue, even though are individual or social. In this context, these problems have been experienced as a bias and acceptance problems, according to the following talks:

It had prejudice in church I walked, I saw some ladies talking about my problem and we knew that they were with prejudice, then I left the church and went into depression when I got in the bank, which only had a place that was full I sat, I sat in that place there was no one, near the other brothers and other sisters, and they disguised, stay sitting a little, then rose and 
went to sit in another corner, they spoke to me by far, not embraced, that before the end of the cult, they embraced, took in hand but so far, we knew that they were in schism of something, then I talked to the pastor and he said no, I did not see prejudice, then he said from today you will sit in front with me, you believe that I sat between him and his wife, the pastor, she got up, and was there for the church door outside and left the corner of the empty seat, and chair was unoccupied during the all the cult, and no one else sat, oh ready I did not say anything to the pastor, I was disgusted, left the church, and no one was in my house hit despair then I fall in the world...

Antônio, 54 years.

No, no one knows, not tell anyone.

Madalena, 32 years.

Prejudice and discrimination are experienced daily in society by people with HIV, the syndrome is still surrounded by paradigms and uncertainties, which make the infected themselves do grip of a silence that prevent them clarify their doubts and facing better form their conditions of having an incurable disease, which, but with treatment will be a better estimate of life and quality of the same [24].

Positive sera adhere to silence as a form of protection and prevention of possible bias that may receive, they have fear that after the discovery of society that they are HIV positive, this discovery may lead to social exclusion, and that way they are excluded themselves. Silence joined generates the positive sera the condition of not having anyone to share and clarify their doubts, fears, anxieties about his current health condition, putting them in a vulnerable situation [25].

Prejudice, fear and social exclusion are factors that characterize the epidemic of striking and unusual way. Having HIV is living with an individual and social burden by guilt. Sera positive for HIV tend to face lack in emotional relationships whether in family or social, and in sexuality. This generates feelings of rejection and fear, these difficulties can lead to psychological and physical damage thus impairing their quality of life [26].

Human behavior is patterned by an act "right" or "wrong" that bind the society to follow in ways considered desirable, so that biased concept of the disease have to be overcome in the social sphere, to prevent self-image of being different or abnormal for being HIV positive [27].

\section{Plans for the Future}

Asked about what would be the plans for the future, both of respondents demonstrate just want to move forward in a peaceful and happily way with their family, children and husband.

My plan is to go on my way, at church and always stick with my family, living a normal life in peace, because work I can not anymore, this I know that I can not, even told by doctors, working in warmth, avoid sunbathing hot, dust, was more what Dra. Sonia recommended me. Antônio, 54 years.

I want to be very happy with my children, and continue my life.

Madalena, 32 years.

The lack of clarification and knowledge about what is SIDA linked to the normally biased way to face this epidemic takes infected people to express, in the most varied ways, their feelings about this syndrome. The erroneous way in which the epidemic has been associated with specific groups and for being an STD (sexually transmitted disease) and linked to death, helping people to develop, with different forms and intensity of demonstrations, a sense of irrational fear about the diagnosis of HIV infection [28].

Following some theoretical models, it attempts to explain the emergence of this feeling of fear 
that people develop in relation to SIDA, doing an integration of cognitive, psychoanalytic and physiological theories of tension and "stress" that, according to the authors of the theories, comes from a extrinsic stimulus termed as being superior to individual adaptation mechanisms of their new health condition.

\section{Final Considerations}

This research allowed us to understand in a more comprehensive way some problems that arise in the SIDA disease. Especially those relating to the prospects of life and disease coping alternatives, by addressing issues involving aspects of everyday experiences of respondents.

With this study it can be identified the phases of the pathology in which respondents were, one patient was in asymptomatic phase, which is the phase to be HIV positive, and the other at the stage of full-blown SIDA, with signs and symptoms quite specific.

It was noted in interviews that the best way to combat the disease begins with the very acceptance of the pathology for the individual infected. With the lack of clarification and truthful knowledge about what it is about the SIDA disease, and the connection in the usual biased way to face this epidemic, it induces infected individuals to express, in the most different ways, their feelings before the syndrome, from despair to disbelief of being a carrier of the disease.

The HIV infection, more than a problem to be faced by health services, should be considered a social and cultural phenomenon quite complex, where there is a very large discrimination with carriers and a lot of lack of knowledge by the public about this infection, meriting the use of new methodological approaches and promoting public equity policies to improve the quality of life of patients.

\section{References}

1. Gomes, Amt; Silva, Emp; Oliveira, DC. Representações sociais da AIDS para pessoas que vivem com HIV e suas interfaces cotidianas. Rev. Latino-Am. Enfermagem, v. 19, n. 3, p.485-492, 2011.

2. Brasil. Ministério da Saúde. Portal do Programa Nacional de DST e AIDS do Ministério da Saúde do Brasil. Disponível em: http//www.aids.gov.br acesso em: 15 abril de 2014.

3. Motta, MGC. Et al. Vivências da criança com HIVIAIDS doi: 10.4025/ciência cuidado de saúde. Ciência, Cuidado e Saúde, v. 11, n. 4, p. 681-686, 2013.

4. Junqueira, Mfr, et al. Enfrentamento de pessoas com hiv/aids. Goiânia. Rev Saúde Pública, v.9, n.16; p.22-31, 2013.

5. Schwartz, T; Vieira, R; Geib, Ltc. Apoio social a gestantes adolescentes: desvelando percepções Social. Ciência \& Saúde Coletiva, v.16, p.2575-2585, 2011.

6. Brasil. Ministério da Saúde (BR). Secretaria de Vigilância em Saúde. Programa Nacional de DST e AIDS. Manual de adesão ao tratamento para pessoas vivendo com HIV e AIDS. Série A. Normas e manuais técnicos. Brasília (DF): Ministério da Saúde; 2010. (Série Manuais, $n^{\circ} 85$ ).

7. Brasil. Ministério da Saúde. Secretaria de Vigilância em Saúde. Programa Nacional de DST e AIDS. Manual de adesão ao tratamento para pessoas vivendo com HIV e AIDS. Série A. Normas e manuais técnicos. Brasília (DF): Ministério da Saúde; 2008. (Série Manual, n 84)

8. Moura, El; Souza, Np. Transmissão vertical do HIV: expectativas e ações da gestante soropositiva. Revista Latino-Americana de Enfermagem, v. 14, n. 3, p. 405-413, 2006.

9. Prodanov, Cc; Freitas, Ec. Metodologia Do Trabalho Científico: métodos e técnicas da pesquisa e do trabalho acadêmico. 2. ed. Rio Grande do Sul: Universidade Feevale, 2013. 277 p.

10. Brasil. Conselho Nacional de Saúde/Ministério da Saúde (CNS/ MS). Resolução No 466/2012 do, e em suas complementares (Resoluções CNS/MS 240/1997, 251/1997, 292/199, 303/2000, 304/2000, 346/05 e 347/05. Brasília: MS, 2012.

11. Nakamura, Fy; Moreira, A; Aoki, Ms. Monitoramento da carga de treinamento: a percepção subjetiva do esforço da sessão é um método confiável. Revista da Educação Física/UEM, v. 21, n. 1, p. 1-11, 2009.

12. Fonseca, C. Quando cada caso NÃO é um caso: pesquisa etnográfica e educação. Rev. Bras. Educ., Rio de Janeiro, n. 10, abr. 1999. 
13. Minayo, Mcs. Análise Qualitativa: teoria, passos e fidedignidade. 12 ed. São Paulo: Hucitec, 2012, p 621-626.

14. Carvalho, Ft; Piccinini, CA. Aspectos históricos do feminino e do maternal e a infecção pelo HIV em mulheres. Ciênc Saúde Coletiva, v.13, n. 6, p.1889-98, 2008.

15. Grangeiro, A; et al. Caracteristicas da resposta a AIDS de secretaria de saude, no contexto de políticas de insentivo do Ministerio da Saude, Saúde soc.; v.21, n.4, p.954-975, dez. 2012.

16. Ferreira, Be; Oliveira, Mi; Piniago, Amm. Miranda. Qualidade de vida de portadores de HIVIAIDS e sua relaçao com Linfocitos CD4+, Carga Viral e Tempo de diagnóstico. Rev. bras. epidemiol. v. 15, n.1, p. 75-84, mar. 2012.

17. Cardoso, Al; Marcon, Ss; Waidman, Map. O impacto da descoberta da sorologia positiva do portador de HIVIAIDS e sua família. Rev. enferm. UERJ, Rio de Janeiro, v.16, n.3, p.326-32, jul. Set. 2008.

18. Cavalcante, Mbpt; Alves, Mds; Barroso, Mgt. Adolescência, álcool e drogas: uma revisão na perspectiva da promoção da saúde. Esc Anna Nery Rev Enferm, v. 12, n. 3, p. 55-59, 2008.

19. Renestol, Hmf. Et al. Enfrentamento e percepção da mulher em relação à infecção pelo HIV. Rev Saúde Pública, v.48, n.1, p.3642, 2014.

20. Bellenzani, R; Nemes, Mib. Avaliação de uma intervenção psicossocial no cuidado em adesão ao tratamento por HIV/Aids: um estudo de caso. Temas em Psicologia, v. 21, n. 3, p. 765-789, 2013.

21. Salles, Cmb; Ferreira, Eap; Seidl, Emf. Adesão ao tratamento por cuidadores de crianças e adolescentes soropositivos para o HIV. Psic Teor e Pesq, v. 27, n. 4, p. 499-506, 2011.

22. Suit, D; Pereira, Me. Vivência de estigma e enfrentamento em pessoas que convivem com o HIV. Psicol USP, v.19, n.3, p. 31740, 2008.

23. Almeida, FJ. et al. Diversity and prevalence of antiretroviral genotypic resistance mutations among HIV-1-infected children. J. Pediatr, Rio de Janeiro, v.85, n.2, p.104-9, 2009

24. Costa, Tl; Oliveira, Dc; Alexandre, Fg. "Representações sociais sobre pessoas com HIVIAIDS entre enfermeiros: uma análise estrutural e de zona muda." Estudos e Pesquisas em Psicologia, v.12, n.1, p.242-259, 2012
25. Sousa, Pkr, et al. "Vulnerabilities present in the path experienced by patients with HIVIAIDS in treatment failure." Revista brasileira de enfermagem, v. 66, n.2, p. 202-207, 2013

26. Galvão, Mtg, et al. "Estratégias de mães com filhos portadores de HIV para conviverem com a doença." Cogitare Enferm. v. 8, n.2, p. 230-7, 2013

27. Gubert, Fa; Vieira Nfc; Damasceno, Mmc; Lima, Fet; Ximenes Lb. Escalas para medida de comportamento preventivo em meninas adolescentes frente às dst/hiv: revisão integrativa. Rev Gaúcha Enferm., Porto Alegre (RS) 2010 dez; 31(4): 794-802.

28. Carvalho, Ft. et al. Fatores de proteçao relacionados á promoçao de residencia em pessoas que vivevem com HIVIAIDS. Cad. Saúde Pública, v. 23, n.9, p. 2007-09,set. 2009.
Publish in International Archives of Medicine

International Archives of Medicine is an open access journal publishing articles encompassing all aspects of medical science and clinical practice. IAM is considered a megajournal with independent sections on all areas of medicine. IAM is a really international journal with authors and board members from all around the world. The journal is widely indexed and classified Q1 in category Medicine. 